thrust into its stead in iii 6 and iv ro; xviii 6 there should be a colon after ego, and in $v .9$ a comma after loquere; xxiii 15 ad is corrected to $e t$, but more probably it stands for adq. or ac; xxvi 29 a comma is wanting after sum. In I St John ii I I I have recently discovered $h^{*}$ wrote am[bulat, not ea[t; in $v .14$ ag[nouistis, not co[nowistis; in 0.19 palam, not praesto; and in iii 2 ignorat, not egnorat. In Apocalypse ix I I would punctuate after fornace with a full stop, since qui which follows must refer to angelus.

The brackets employed for restoring clipped away letters might with advantage have been omitted in many places where the Editor has inserted them, viz 2 St Peter i 5 subminis[trate in] fide, v. 7 [amorem], v. II int[roitus in]; Acts xviii 12 [cum] esset, v. I 7 [se non] uidere; Apocalypse xii 13 [perse]cutus and perper[erat]. In these and not a few other instances the reading is by context and by space and by surviving letters nowise doubtful.

In conclusion I would take this opportunity to add two new restitutions to the text of $h$ in Acts xviii 2, [iudea pris]cilla and claud[ius caesar. Also from my recent rescript of the Old-Latin Version of the Catholic Epistles from the Perpignan MS $(p)$, which I hope to publish in the next number of the Journal of Theological Studies, I would supply from $p$ in 2 St Peter i 8 cum which has fallen out of the MS after $u$ obis (von Soden has already proposed $s i$ ), and in $v .17$ I would with $p$ now edit [accepit eni-] for [accipiens].

In the Journal of Theological Studies for July 1910 Dr Alexander Souter suggests that in Acts xxvi 22 co[nsecutus should be read in $h$ for $\operatorname{co[nfisus.~The~space~at~the~end~of~a~line~cannot~determine~absolutely~}$ the number of letters clipped away, and, therefore, though consecutus seems a little too long, no argument can be final on merely space considerations. But gig has usus which looks like a miscopying of fisus, and confisus I think is more Pauline in thought than consecutus. In 2 Cor. ii 4 St Paul joins confidentiam and ability to stand. In spite of my learned friend's advocacy of consecutus, my own vote is still for confisus.

E. S. Buchanan.

\title{
IRISH PSALTERS.
}

The glossed Coupar-Angus Psalter (MS Vatic. Palat. lat. 65), of which I have recently given a short description, prefixed to 'Specimen pages of two manuscripts of the Abbey of Coupar-Angus in Scotland' (Codices e Vaticanis selecti phototypice expressi, \&c. Series minor. Vol. ï. Roma 
1910), seemed to demand in addition not only a full list of its contractions (see Keltische Zeitschrift für Philologie viii pp. 246-257) but a short note as to its liturgical evidence.

In this Psalter of insular script, which was copied at the end of the twelfth or even the beginning of the thirteenth century and was in the possession of the Coupar-Angus house in the thirteenth, there are inserted, after Psalms l, c, and cl, the seven Old Testament Canticles which the Roman Breviary assigns for use at Lauds from Sunday until Saturday, and four prayers; the arrangement, however, is not consistent, for whilst the Canticles precede the Prayers after Psalms $\mathrm{c}$ and $\mathrm{cl}$, the Prayer comes first after Psalm 1; the sequence is :

After Ps. 1.

Prayer i Deus altissime.

Canticle i Benedicite omnia opera.

ii Confitebor tibi domine.

$" \quad$ iii Ego dixi in dimidio (the end is missing as a leaf has been cut out).

After Ps. c. Canticle iv Exultavit cor.

" v Cantemus domino.

$"$ vi Domine audivi.

Prayer ii (inserted by a later hand) Deus quem exercitus.

After Ps. cl. Canticle vii Audite celi.

Prayers (by the later hand)

iii Te dominum de celis.

iv Deus qui exeunti.

This, however, can scarcely represent the use of a Cistercian house at the time when the MS was written; it is more probably a copy, more or less accurate, of the exemplar which, in this instance, to judge by some palaeographical marks, was probably the product of some North English scriptorium in the eighth century.

It would have been interesting to trace the gradual developement of the Psalter by the addition of canticles and prayers, the former of which go back to Esdras, who is said to have collected the Biblical Canticles and added them to the book of Psalms; the latter to the Eastern usage, which is as early as the fourth century, of saying a collect instead of Gloria patri at the end of each psalm; and it would have been easy to draw up an eight or ninefold division of psalters, whether copied for public or for private use, founded on the insertion of collects or canticles or both, and their position after each psalm, after Psalm cl or at the end of each third of the Psalter. This might, however, trench on the domain of an English liturgiologist who is treating this subject, and 
the present enquiry is confined to the last subdivision, viz: canticles and prayers inserted after Psalms l, $c$, and $\mathrm{cl}$.

All known Psalters in insular script which contain anything more than the 150 Psalms and were written in Ireland or Scotland ${ }^{1}$ are arranged in this way $^{8}$; and in this respect they bear out the tradition that St Patrick and the early Irish monks recited every day the whole psalter in three divisions." It would not be fair to pass over Mr F. E. Warren's expressed doubt (loc. cit.) as to whether these canticles and prayers were added to mark the break into three books and without any special liturgical significance; but it seems more reasonable to accept the traditional use until it can be disproved on historical evidence. At any rate we can compare the extant manuscripts; and, not contenting ourselves with a general statement as to their contents, "we are able to reconstruct exactly the arrangement which is common to them all. The MS sources are :

a. B. M. Cotton. Vitellius F. XI, of the end of the ninth century, is much damaged by fire ; the leaf containing Canticle ii is bound in wrong order, and another one is missing after Ps. 1 12, after which follow Canticles ii and iii; Prayer ii and Canticles iv-vi follow after Ps. c. The MS now ends with Ps. cxlv 7.

b. St John's College, Cambridge, C. 9, the 'Southampton Psalter', written about A. D. rooo.

After Ps. 1 Prayer i; Canticles i-iii.

" ", cl " $"$ ii ; Canticle vii.

c. B. M. Reg. Galba A.V., of the eleventh century, said to have contained the words 'Liber Oswini Regis', probably a copy of a Psalter written at the end of the seventh century. There is a lacuna between Pss, xlix and li.

After Ps. c, Canticles v, vi, ii. The end of the MS is defective; the penultimate leaf extends as far as Ps. cxlviii 4; part of a prayer is visible on the last leaf.

d. B. M. Add. MS. 369ag. Saec. 13.

After Ps. 1; Canticles i-iii.

" " c; " iv-vi.

" " cl ; Prayer iii, Canticle vii.

1 The four Irish Psalters at St Gall have the Canticles at the end of the Ptalter.

- F. E. Warren The Bangor Antiphoner ii p. x.

3 Thomasii Opp. ommia ed. Vezzosi II (Romae 1747) ad. Lectorem Ia and a.

- Neither the description of the Southampton Paalter in the two volumes of the Irish Liber Hymmonum (H. B. S.), nor that of B. M. Add. MS. $3^{6029}$ in the 1907 Catalogue of Additions to the MSS, gives a complete account of the Prayers and Canticles. 
e. Vatic. Palat. lat. 65. See above.

f. Ambros. C. 5 inf. The Bangor Antiphoner, saec. vii ex, not being a Psalter, the exact position and relation of its contents is uncertain; but Prayers i-iii are each appointed as a 'Collectio post Laudate dominum de caelis', i. e. Pss. cxlviii-cl and Prayer iv as the first 'Collectio post Cantemus', i.e. Canticle v.

The text of the Canticles, which, with a few variations, is that of the Vulgate, is not here in question.

The four prayers appear in the Vatican MS as

I.

Deus altissime rex angelorum. deus laus omnium elimentorum. deus gloria ${ }^{1} \&$ exultatio sanctorum custodi animas seruorum tuorum qui regnas in secula seculorum."

[The above arrangement of this and the following prayer, which does not appear in the MS, is given for the sake of the rhyme.]

In $b$ and $f$ gioriacf "wanting in $f, b$ adds $A$ mon.

II. (By later hand.)

Deus quem exercitus canit ${ }^{1}$ celorum' quemque ecclesia ${ }^{3}$ laudat ${ }^{4}$ sanctorum quem spiritus ministrat ${ }^{3}$ uniuersorum miserere obsecro "omnium nostrorum" qui regnas in secula seculorum. Amen.

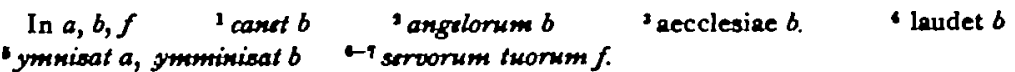

III. (By later hand.) Te dominum de celis laudamus tibi ut canticum nouum cantare mereamur. $\mathrm{Te}$ dominum in sanctis tuis uenerabiliter deprecamur ut omnia uota nostra suscipias ${ }^{1}$ peccata dimittas Christe ${ }^{2}$ saluator mundi qui regnas in secula seculorum. Amen.

$$
\text { In } b, d, f
$$

$b$ has the first five words and then continues:

$$
\begin{aligned}
& \text { teque omnium regem regum rogamus } \\
& \text { tibi uni et trino in quem speramus } \\
& \text { cum excelsis angelis imnum canimus } \\
& \text { per dominum nostrum et reliqua. }
\end{aligned}
$$

1 suscipict d wanting in $f$. 
IV. (By later hand.) Deus qui exeunti ex egipto populo tuo maria diuisisti \& suspensis utrinque marginibus in specie muri eregi ${ }^{1}$ fluenta ${ }^{9}$ iussisti, animas quoque nostras a diluvio peccatorum liberare digneris ut transire viciorum gurgitem [ualeamus]' hoste contempto saluator mundi, qui "regnas" in s[ecula] s[eculorum]. Amen.

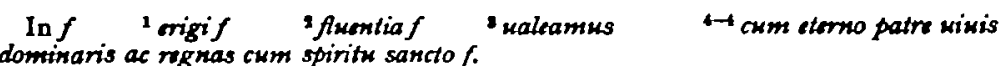

We are thus able to reconstitute the typical and, perhaps, primitive Irish psalter as providing one prayer and a canticle or canticles at the end of each of the three books of the Psalter, thus :

$$
\begin{gathered}
\text { After Ps. l Prayer i; Canticles i-iii. } \\
" \Rightarrow \text { c " ii; } " \text { iv-vi. } \\
" \Rightarrow c l \text { iii; Canticle vii. }
\end{gathered}
$$

The only exceptions to the above order are that $c$ has the Canticles in different order; and that, the original scribe of $e$ having omitted to copy in their proper places Prayers ii and iii, a corrector has inserted them in vacant spaces after the canticle which they should have preceded; and in order to fill up the last page of the MS has inserted Prayer iv which is only found in Irish MSS.

H. M. BANNISTER.

\section{THE SEVEN LETTERS AND THE REST OF THE APOCALYPSE.}

In his important work on the Letters to the Seven Churches, for which so many readers feel themselves his debtors, Sir W. Ramsay somewhat provokingly puts forward the theory (c. iv, \&c.), that the Letters themselves have no organic connexion with the main portion of the Apocalypse which, he considers, 'is complete without them'. He looks upon them as forming a mere episode, attached loosely to a work of diverse character, as a kind of homiletic addition, the idea of which only occurred as an afterthought to the Sacred Writer during the process of penning the Apocalypse proper. Accordingly, though they are, as a matter of fact, found at the beginning of the book, he holds that there is no reason why they should have been given that position rather than any other, except perbaps for convenience' sake. The link of connexion, therefore, with the rest of the book is, in his riew, but a slender, a mere formal one, an artificial bridge to unite the two- 